\title{
BLACK SILICON QUALITY CONTROL BY CONDITIONS OF NICKEL-ASSISTED ETCHING OF CRYSTALLINE SILICON SURFACES IN PHOTOVOLTAIC DEVICES
}

\author{
M. Kamarauskas, M. Treideris, V. Agafonov, A. Mironas, V. Strazdienè, \\ A. Rèza, and A. Šetkus \\ Center for Physical Sciences and Technology, Sauletekio 3, 10257 Vilnius, Lithuania \\ Email: mindaugas.kamarauskas@ftmc.lt
}

Received 30 May 2019; revised 28 October 2019; accepted 3 December 2019

\begin{abstract}
Here we present a study of the nickel-assisted etching applied to form uniform black silicon layers on crystalline silicon substrates. We related the parameters used for technological process control (etchant, nickel thickness) to parameters of the obtained surface and explain the correlation using the etching model responsible for etching of the silicon covered by a thin nickel film. The increase in the thickness of the metal catalyst did not suppress the etching completely but allowed one to tune the roughness of the silicon surface. The rate of the electrochemical etching was additionally changed by adaptation of the proportion of components in the complex etchant. Depending on the intentionally selected conditions, the duration of the optimized process was from 3 to $10 \mathrm{~min}$. The lowest optical reflection commonly accepted as the black silicon surface was obtained for the mixture with a low amount of the active etchant component. It was demonstrated that the method is acceptable to improve the characteristics of a photovoltaic cell.
\end{abstract}

Keywords: silicon etching, metal-assisted etching, black silicon, light trapping, photovoltaic cell

PACS: $81.16 .-\mathrm{c}, 81.16 . \mathrm{Rf}$

\section{Introduction}

Despite new concepts and technologies proposed for the new generations of photovoltaic (PV) devices, silicon solar cells are still dominant in the market with more than $90 \%$ percent share of the installed PV power [1]. However, there is still a great demand for an increase in the silicon PV efficiency and a decrease in the manufacturing costs. One of the commonly accepted ways to increase the PV cell efficiency was the light management on the cell surface. It was proved that the 'black silicon' (black- $\mathrm{Si}$ ) is an acceptable method to reduce the reflectance of the Si PV cell surface down to the minimum [2]. Black-Si was commonly accepted as the nano- and micro-structured silicon surfaces that effectively suppress reflection, while simultaneously enhancing the scattering and absorption of light and a black look instead of a silver-gray look of pure silver wafer [3]. Until now, diverse methods have been proposed for the formation of black-Si including reactive ion etching (RIE) [4], metal-assisted etching with gold [5] or silver [6] nanoparticles, electrochemical etching, etc. The black-Si formation using one- [7] or two- [8] step nickel nanoparticlesassisted etching was also demonstrated. Unfortunately, there are serious drawbacks that highly 
limit application of these methods. High costs practically eliminated RIE from the mass production. The absence of practically effective methods to remove gold residues from the surfaces excluded Au-nanoparticles-assisted etching from the cell technology. Metal-assisted etching using a silver catalyst significantly changed the doping level of silicon surfaces due to the silver diffusion into silicon. Nickel-assisted etching using nanoparticles lacks control over a catalyst size and thus on the morphology of the formed structure. Electrochemical etching is effective for small samples but it can hardly be controlled over large area samples. Therefore, there is still a great practical demand to develop the methods for the cost-effective blackSi formation on large area surfaces of Si PV cells for the future of black-Si photovoltaics.

In our previous work [9], we demonstrated that it is possible to form black silicon by cost-effective and well-controlled formation technology using nickel-assisted chemical etching (NACE) and an ultrathin nickel film as a precisely controlled catalyst for etching. In this work, we investigate the influence of key technological factors on the formation of black-Si by this approach. This work describes the technological processes and their parameters that result in the influence on the optical reflection of the black-Si coated surfaces. A possibility to adapt the modified NACE to tune the parameters of a model PV solar cell is demonstrated.

\section{Experiment}

In the experiments, we used the commercially available silicon wafers obtained from SIEGERT WAFER $G m b H$. It was the p-type Czochralskigrown crystalline silicon (CZ c-Si) with the (100) orientation. The electrical resistivity was about 1-5 $\Omega \mathrm{cm}$. Before our experiments, the c-Si substrates were carefully prepared by the standard procedures commonly used in the semiconductor device production. For the NACE experiments, the c-Si samples were initially covered with thin nickel layers $\left(d_{\mathrm{Ni}}=10-80 \mathrm{~nm}\right)$. DC-magnetron sputtering was used for this. The Ni-coated samples were treated in a HF: $\mathrm{H}_{2} \mathrm{O}_{2}: \mathrm{H}_{2} \mathrm{O}$ etching solution for a fixed duration. The proportions of components in the etching solutions were intentionally selected for each experiment individually. The in- fluence of the etching duration on the surface properties of the samples was studied by changing the etching time in the interval from 1 to $20 \mathrm{~min}$.

For the investigations of the influence of etching on the electrical characteristics of photovoltaic cells we fabricated a simple model of PV devices. The $\mathrm{p}-\mathrm{n}$ junction was formed by using phosphorus diffusion from phosphosilicate glasses (PSG). A solution consisting of TEOS: $\mathrm{C}_{2} \mathrm{H}_{5} \mathrm{OH}$ : $\mathrm{H}_{2} \mathrm{O}: \mathrm{HCl}=5: 10: 1: 0.1$ (kept for $24 \mathrm{~h}$ ) was mixed with phosphoric acid and was deposited by spincoating. The structure was dried for $1 \mathrm{~h}$ at $80^{\circ} \mathrm{C}$ in ambient atmosphere. Two-step diffusion was performed in the tube furnace SVCS from SVCS Process Innovation: the first step was annealing for $1 \mathrm{~h}$ in $950^{\circ} \mathrm{C}$ and nitrogen atmosphere, after the PSG removal the second diffusion step was annealing for $1 \mathrm{~h}$ in $950^{\circ} \mathrm{C}$ and nitrogen atmosphere. After the diffusion process, the residue of the reaction was removed by immersing the samples in the dilute HF solution. Ohmic contacts were formed by deposing $\mathrm{Al}$ paste on the back side of the $\mathrm{p}-\mathrm{Si}$ substrates and by sputtering Ag on the front side of the model sample. Before the tests the edges of the samples were mechanically cut.

The surface morphology was characterized by a scanning electron microscope Helios NanoLab 650 by FEI and a scanning probe microscope SPM-Dimension 3100/Nanoscope IVa from Veeco Metrology. Analysis of the surface images was performed using the software package Gwyddion [11].

The optical reflectance was measured using a Shimadzu UV-3600 spectrometer with an integrating sphere. The reflectance was measured in the interval of light wavelengths from 400 to $1100 \mathrm{~nm}$.

\section{Results and discussion}

\subsection{Etching model}

Our experiments were based on the commonly known principles of metal-assisted c-Si etching that were developed for the noble metal catalystassistant etching. In our study we modified this model by adding specific details about the Ni film properties.

The mechanism was thoroughly described and proposed in [11]. The model explained the c-Si etching in an aqueous solution of $\mathrm{HF}$ and $\mathrm{H}_{2} \mathrm{O}_{2}$ 
with the nanoparticles of noble metals, namely $\mathrm{Au}, \mathrm{Pt}$ and $\mathrm{Pd}$. It was proposed that, during metalassisted etching, the metal-silicon interface can be described as a microscopic electrochemical cell with silicon as the anode and metal as the cathode in it. The electrochemical processes can be described by a set of the following equations:

a) on metal surface:

$$
\begin{aligned}
& \mathrm{H}_{2} \mathrm{O}_{2}+2 \mathrm{H}^{+} \rightarrow 2 \mathrm{H}_{2} \mathrm{O}+2 \mathrm{~h}^{+}, \\
& 2 \mathrm{H}^{+}+2 \mathrm{e}^{-} \rightarrow \mathrm{H}_{2} \uparrow ;
\end{aligned}
$$

b) on silicon surface:

$$
\begin{aligned}
& \mathrm{Si}+4 \mathrm{~h}^{+}+4 \mathrm{HF} \rightarrow \mathrm{SiF}_{4}+4 \mathrm{H}^{+}, \\
& \mathrm{SiF}_{4}+2 \mathrm{HF} \rightarrow \mathrm{H}_{2} \mathrm{SiF}_{6} .
\end{aligned}
$$

According to [12], reactions (3) and (4) occur in the metal-silicon interface due to the hole injection to silicon under metal. The process is controlled by the $\mathrm{H}_{2} \mathrm{O}_{2}$ decomposition (Eqs. 1, 2) stimulated by the metal catalyst. The reaction mechanism can be summarized by a single equation, as proposed by Charter et al. [13]:

$$
\mathrm{Si}+6 \mathrm{HF}+n \mathrm{~h}^{+} \rightarrow \mathrm{H}_{2} \mathrm{SiF}_{6}+n \mathrm{H}^{+}+\frac{4-n}{2} \mathrm{H}_{2} \uparrow .
$$

From reactions (1)-(5) it can be obtained that the etching rate is dependent on the intensity of the hole injection to silicon. The processes are controlled by the catalyst because the hole injection rate depends on the metal catalyst.

It was demonstrated in [14] that $\mathrm{H}_{2} \mathrm{O}_{2}$ decomposes on the nickel catalyst and, consequently, reactions (1)-(5) can be used for the description of the nickel-assisted etching. As a result, the $\mathrm{H}_{2} \mathrm{O}_{2}$ decomposition on the $\mathrm{Ni}$ catalyst surface produces an injection of the holes into silicon. After that, the silicon atoms are removed by the HF etching solution.

The reaction mechanism also includes the mass transport from and to the reaction zone during the process, as described in [15]. More details for the metal-assisted chemical etching mechanism of silicon can be found in the review [12]. The mass transport is very important in the metal-assisted etching and, consequently, in the NACE in our experiments.
It can be concluded from the commonly accepted model of the mechanism that there are a few key factors that control the NACE processes such as the mass transport from the reaction zone, the thickness of the Ni catalyst and the proportions of the components $\mathrm{HF}$ and $\mathrm{H}_{2} \mathrm{O}_{2}$ in the etching solution. Therefore we studied an influence of the listed factors on the black-Si properties in our study with the aim to optimize the set of the parameters required to produce the minimum optical reflectance over the shortest etching time.

\subsection{Investigation of the technological key factors for the black-Si formation}

\subsubsection{Investigation of the mass transport from the reaction zone}

The influence of the mass transport on the characteristics of etched surfaces was studied in the special samples with an individual coverage of the surfaces with thin Ni films. The coverage was intentionally changed by photolithography. For this an individual set of strips was formed in the Ni film on each sample. The width of the Ni strips $\left(W_{s}\right)$ was constant for individual samples and was equal to $0.375,0.75,1.5$ and $3 \mathrm{~mm}$. Since the $\mathrm{Ni}$ strips restricted a direct access to the etching surface for the solution, mass transfer was expected in the interface between the $\mathrm{Ni}$ film and Si surface through the channels of an individual length equal to the width of the strips. The dependence of the surface parameters was measured in the samples with an individual length of the mass transport channels. The SEM pictures presented in Fig. 1 show that it is a clear difference between the etched area of silicon where the $\mathrm{Ni}$ film was deposited and where it was not (shown by arrows in Fig. 1(a)).

The analysis of the obtained surface (as presented in Fig. 1(b)) showed the structured layer with a thickness in the range $50-100 \mathrm{~nm}$. For the quantitative description we used atomic force microscopy by scanning the samples directly and scanning with a bigger area of the sample. The AFM images of the same as in Fig. 1 etched silicon surface are illustrated in Fig. 2.

From the AFM measurements it is clear that over a larger scale there are big random variations 

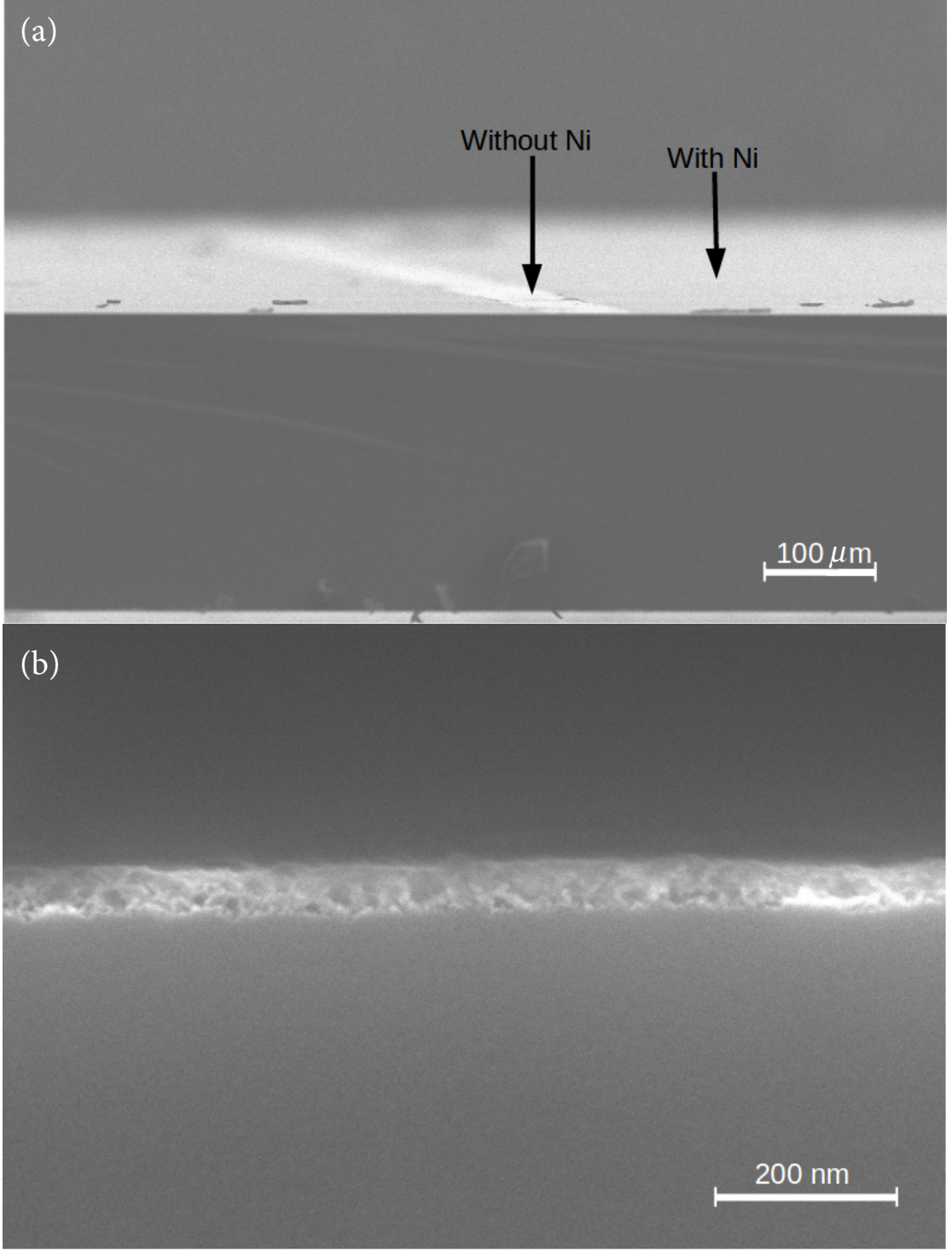

Fig. 1. SEM profile pictures of the etched $\mathrm{c}$-Si surface by the nickel-assisted method (the area, where Ni was deposited and where not, is shown by arrows in (a)). Nickel thickness is $80 \mathrm{~nm}, \mathrm{H}_{2} \mathrm{O}: \mathrm{H}_{2} \mathrm{O}_{2}: \mathrm{HF}=10: 8: 4$, $t=10 \mathrm{~min}$.
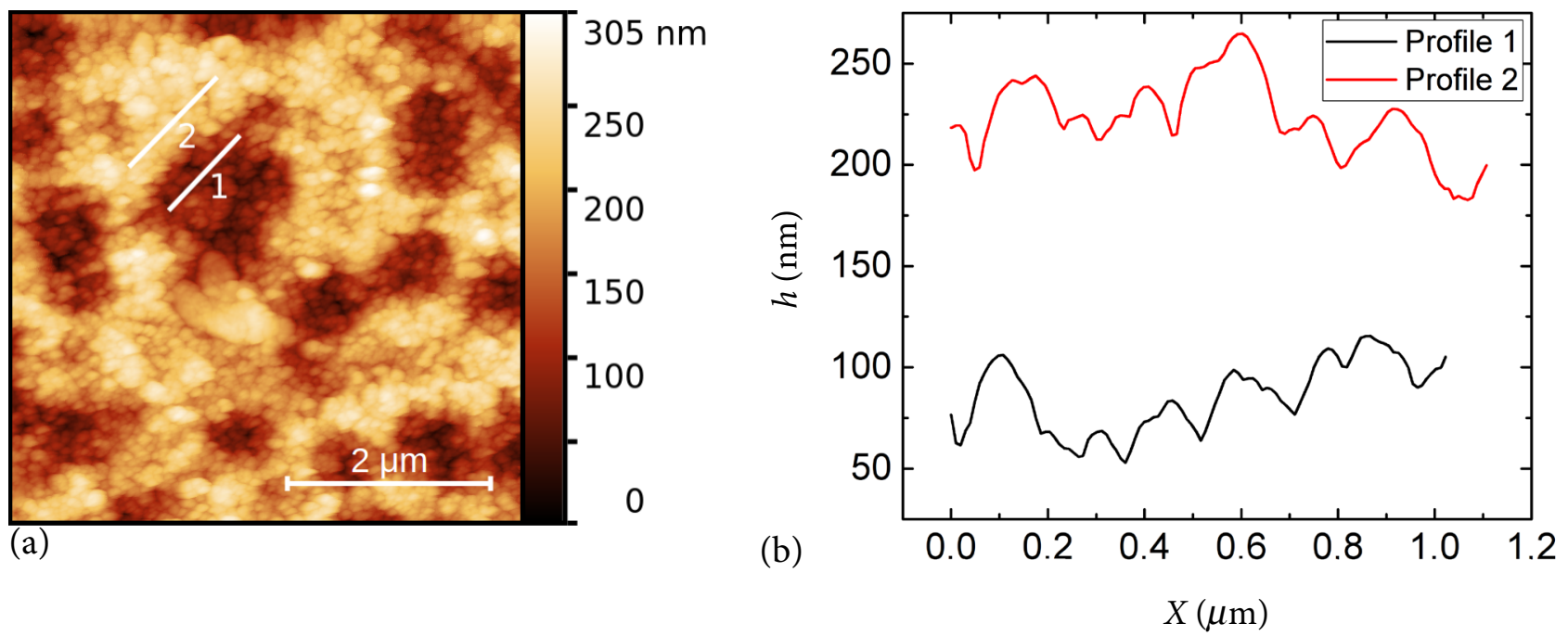

Fig. 2. AFM topography and analysis of the surface profile of the etched $\mathrm{c}$-Si surface by the nickel-assisted method when the nickel thickness is $80 \mathrm{~nm}, \mathrm{H}_{2} \mathrm{O}: \mathrm{H}_{2} \mathrm{O}_{2}: \mathrm{HF}=10: 8: 4, t=10 \mathrm{~min}$. 
of the surface height up to $300 \mathrm{~nm}$; however, on the same sampling area like in the SEM pictures for lower and higher planes on the sample (measured profiles 1 and 2 in Fig. 2(a)) variations in the structure height are the same and have a value range from 50 to $100 \mathrm{~nm}$ (Fig. 2(b)). As bigger height variations are likely to occur randomly we assume that these deviations are from the instabilities of the etchant by itself, so for the further investigation of the Ni film influence we use areas, which are on the same plane, and we analyse smaller height deviations. The variations in the heights of the sample surface produced by $\mathrm{Ni}$-assistant etching were quantitatively characterized by the rootmean-square roughness (RMS) that represented the average of the measured height deviations taken within the evaluation length and measured from the mean line. The RMS parameters were measured in the centre of the Ni ribbon and on the sides of the bare silicon surfaces after the etching. The results of these tests are presented in Fig. 3 .

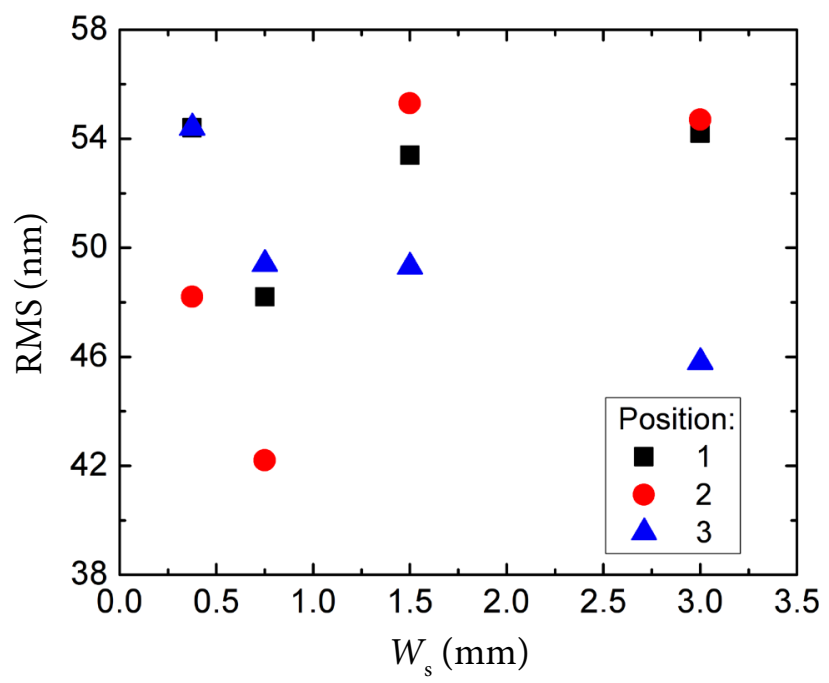

Fig. 3. Surface roughness dependence on the Ni ribbon width in the centre of the ribbon and on the edges.

It must be noted here that the access of etching solution to the surface of substrate can be dependent on the location of surface point and the coverage by catalyst film. Considering this, it was expected that RMS must be dependent on the position under the Ni strip because the mass transport seemed being most effective in the vicinity of the strip edge (positions 2 and 3), whereas the transport effect of the etching solution can hardly be effective over a long distance in the interface channel between the Ni strip and the Si surface. Therefore, the changes produced by $\mathrm{Ni}$-assistant etching were expected being much more visible near the strip edges compared to that far from the edge. Despite this expectation, the results revealed only a very weak influence of the interface channel length on the RMS changes in the Si surface, as can be seen from results in Fig. 2. The mass transport through $\mathrm{Ni}$ films explained the access of etching solution to the Si surface under strips during the NACE in our experiments, and is comparable with the result presented in [11] for different metals during metalassisted etching. Aiming to understand the effect, we have investigated the structure of Ni films.

The AFM imaging of $\mathrm{Ni}$ films revealed a fine grain structure of our strips. The dimensions of grains were measured for the as-deposited Ni catalyst films by the analysis of AFM topography images. Typical results obtained for grain diameters are illustrated in Fig. 4.

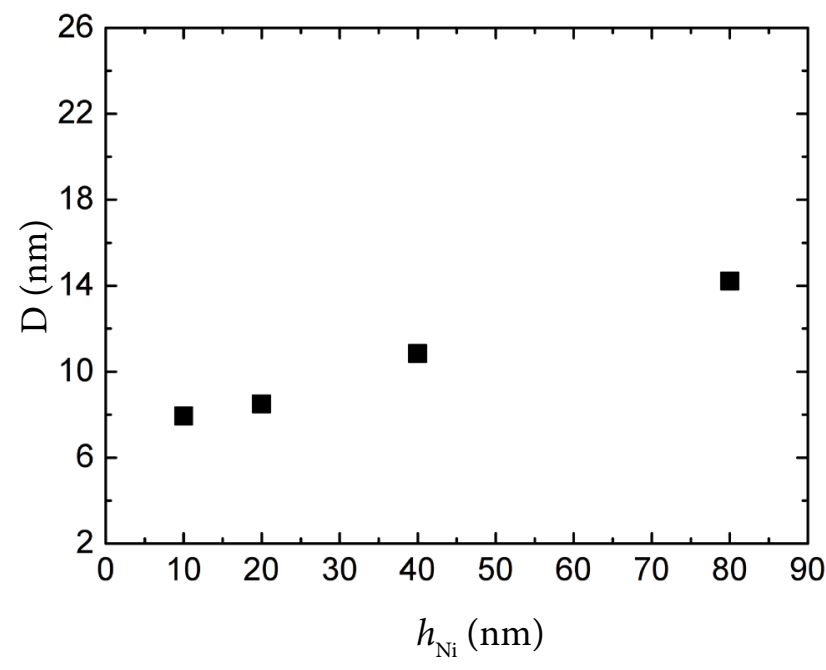

Fig. 4. Average Ni film grain size dependence on the Ni film thickness.

It can be seen from Fig. 4 that the average grain diameter (D) increased with an increase in the $\mathrm{Ni}$ film thickness $\left(h_{\mathrm{Ni}}\right)$. In addition, it was obtained from these measurements that the increase in diameter was followed by a decrease in density of grains in the Ni strips in this study. These results are presented in Fig. 5 .

Based on our results, we think that the mass transport channels were formed between the grains in $\mathrm{Ni}$ films. These channels were sufficiently large for the flow of etching solution through the film 


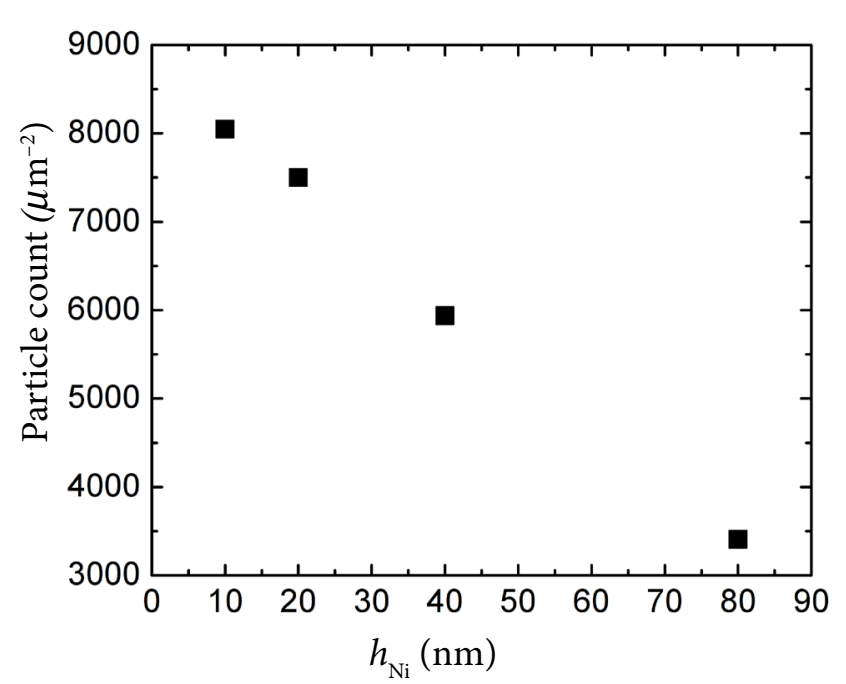

Fig. 5. Density of grains in the Ni catalyst dependence on the Ni film thickness.

to the reaction area. Consequently, the $\mathrm{H}_{2} \mathrm{O}_{2}$ decomposition at Si surface can occur and, hence, the etching mechanism described by equations (2) and (3) can be engaged in Si surface etching. The etching rate for Si surface under metal was dependent on the tunnel-like channels between the grains in $\mathrm{Ni}$ film. The dimensions of these channels were dependent on the density and diameter of the grains in Ni film and, therefore, the surface roughness RMS was changed by the film thickness.

\subsubsection{Ni layer thickness effect on black-Si surface properties}

The influence of Ni layer thickness on the black$\mathrm{Si}$ surface properties was investigated in a series of samples with individual thicknesses of Ni films equal to 10, 20, 40 and $80 \mathrm{~nm}$. These samples were etched in the same etching solution for the same fixed time. The results of RMS analysis are presented for these samples in Fig. 6 .

It can be seen in Fig. 6 that the RMS increased with an increase in Ni film thickness and the maximal RMS was obtained for the $80 \mathrm{~nm}$ thick films.

\subsubsection{Black-Si reflectance dependence on}

the proportions of etching solutions and the etching time

In our experiments, we described the proportions between the components of etching solution by

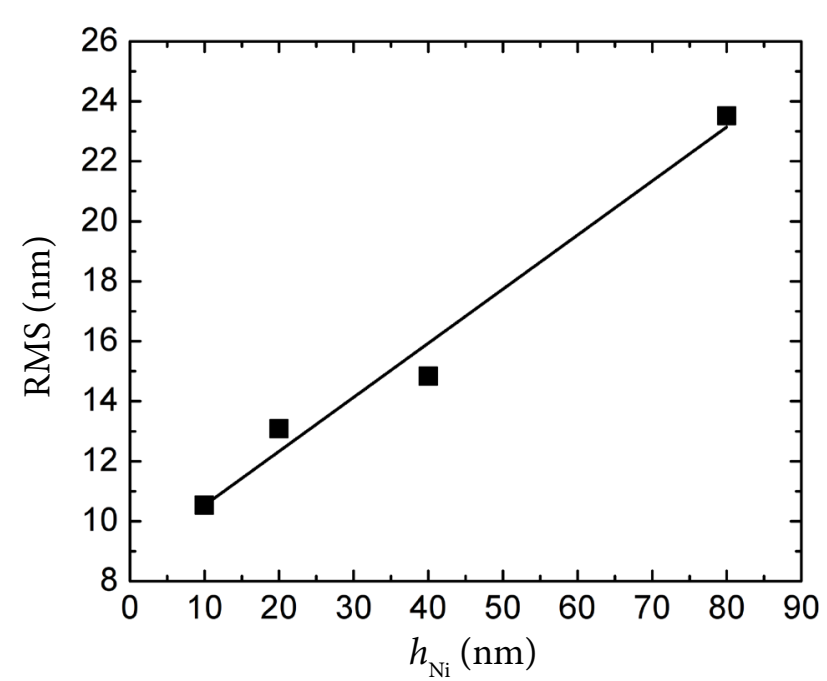

Fig. 6. The dependence of black-Si surface properties on the Ni film thickness. Etching solution is $\mathrm{H}_{2} \mathrm{O}: \mathrm{H}_{2} \mathrm{O}_{2}: \mathrm{HF}=10: 8: 8$, etching time $10 \mathrm{~min}$.

the parameter $\rho$ that was described by the following equation:

$$
\rho=M(\mathrm{HF}) /\left[M(\mathrm{HF})+M\left(\mathrm{H}_{2} \mathrm{O}_{2}\right)\right] .
$$

In Eq. (6), $M(\mathrm{HF})$ and $M\left(\mathrm{H}_{2} \mathrm{O}_{2}\right)$ are the molar concentrations of pure acid HF (48\%, SigmaAldrich) and peroxide $\mathrm{H}_{2} \mathrm{O}_{2}(35 \%$, Eurochemicals). The relationship between the $\rho$ parameter and the amounts of components in the etching solution are listed in Table 1.

Table 1. Etchant volume ratio and representing $\rho$ parameter.

\begin{tabular}{cccc}
\hline$V\left(\mathrm{H}_{2} \mathrm{O}\right), \mathrm{ml}$ & $V(\mathrm{HF}), \mathrm{ml}$ & $V\left(\mathrm{H}_{2} \mathrm{O}_{2}\right), \mathrm{ml}$ & $\rho, \%$ \\
\hline 10 & 8 & 1 & 93 \\
\hline 10 & 3 & 1 & 80 \\
\hline 10 & 1 & 1 & 72 \\
\hline 10 & 8 & 8 & 59 \\
\hline 10 & 4 & 8 & 47 \\
\hline 10 & 1 & 4 & 21 \\
\hline 13 & 1 & 8 & 14 \\
\hline 17 & 1 & 12 & 9 \\
\hline
\end{tabular}

For each $\rho$ parameter in Table 1, the black-Si was produced by etching in the solution for 1,3 , 5,10 and $20 \mathrm{~min}$. The optical reflectance spectra were measured for these samples. The results of etching tests are illustrated by the spectra in Fig. ㄱ. The spectra were obtained for the series of samples 


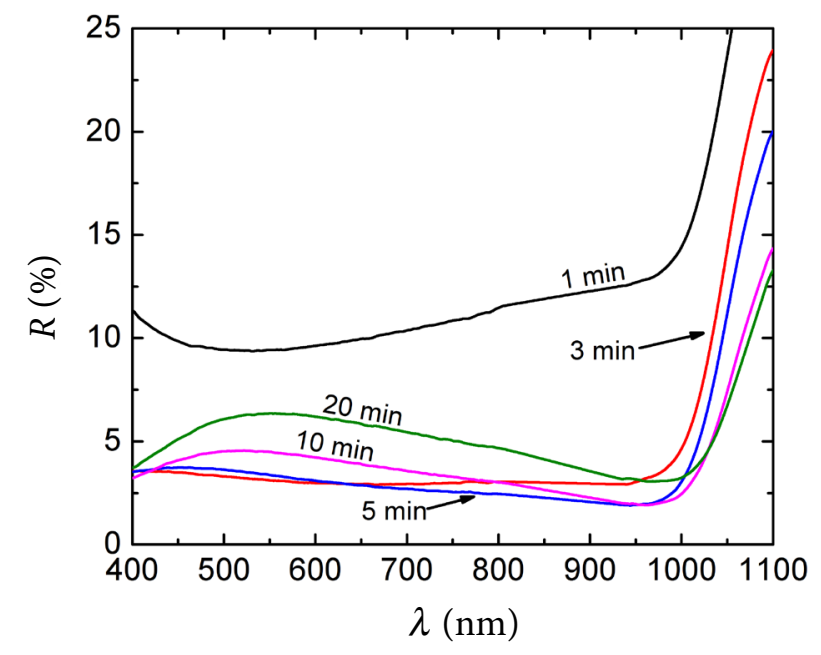

Fig. 7. Reflectance from the black-Si surface etched using an etchant with $\rho=93 \%$ for different time.

etched in the solution with $\rho=93 \%$ for diverse durations from 1 to $20 \mathrm{~min}$.

The influence of parameter $\rho$ on the optical reflectance was characterized by two calculated parameters, namely the average reflectance $R_{\text {avg }}$ and the minimum reflectance $R_{\min }$. The average reflectance was calculated by averaging the optical reflectance over the entire spectra from 400 to $1100 \mathrm{~nm} . R_{\min }$ was obtained by detecting the lowest optical reflectance in the measured spectra. The experimental dependences of these parameters on the parameter $\rho$ and the etching duration are presented in Fig. 8 .

From the results in Fig. 8 it was obtained that there was a non-monotonous dependence of RMS on $\rho$ and etching duration. As it followed from our experiments, the lowest obtained values of $R_{\text {avg }}$ and $R_{\min }$ depended on a certain set of $\rho$ and etching time. The optimal conditions for etching must be identified for an individual pair of the parameters, namely $\rho$ and the etching duration, aiming to obtain the minimal magnitude for $R_{\text {avg }}$ and $R_{\min }$. Our experiments suggested that the lowest value of $R_{\text {avg }}$ was $\sim 2 \%$ and the lowest $R_{\min }$ was $\sim 0.4 \%$ for the black-Si that was formed by the etching under the conditions with $\rho=9 \%$ and duration equal to $10 \mathrm{~min}$.

The SEM pictures of the lowest reflectance value samples are presented in Fig. 9 .

From the SEM pictures it is seen that structures with a width of about $100 \mathrm{~nm}$ and a depth of around $500 \mathrm{~nm}$ have the lowest reflectance value.
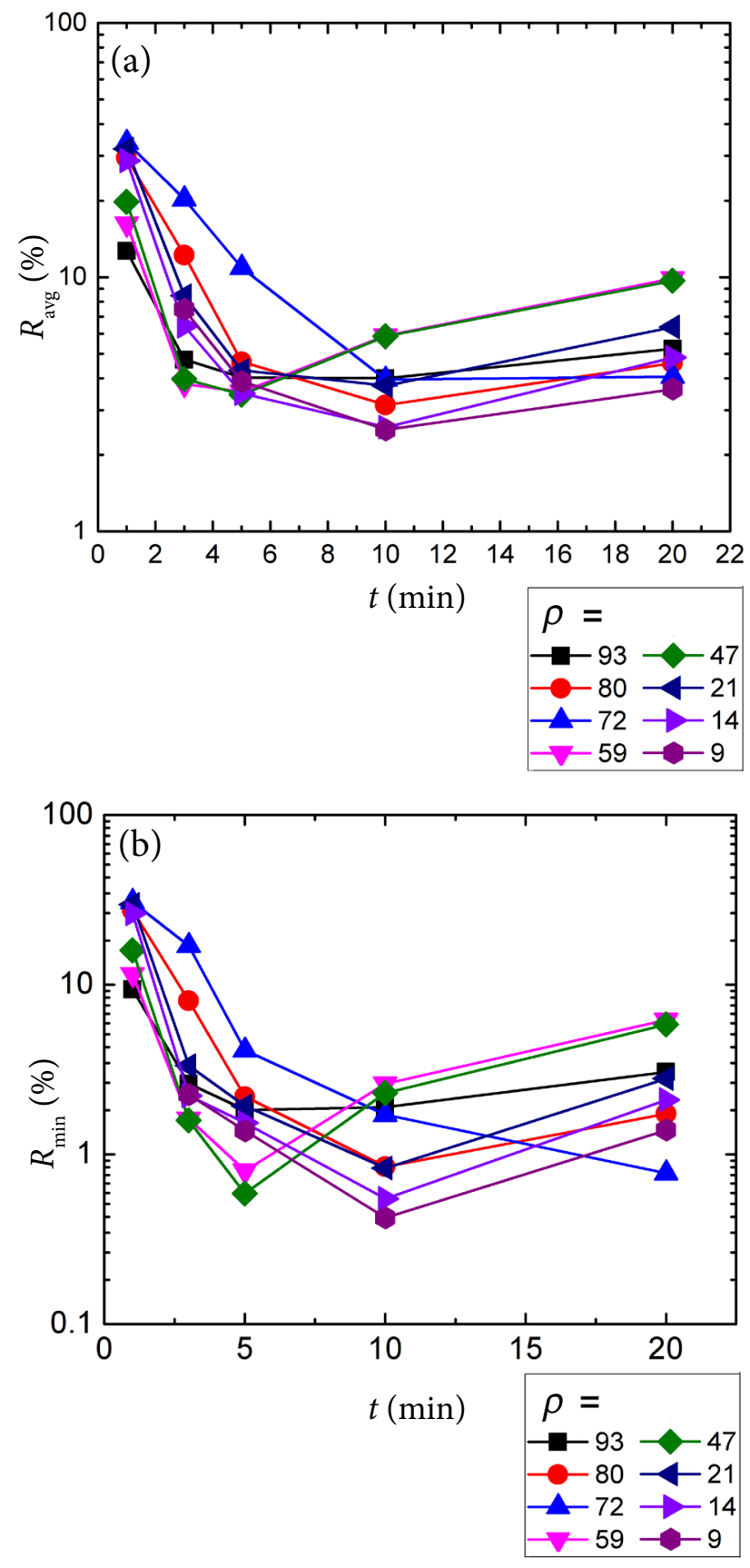

Fig. 8. Average reflectance (a) and minimum reflectance (b) dependence on the etchant $\rho$ parameter and etching time, the $80 \mathrm{~nm} \mathrm{Ni}$ film being used as a catalyst.

\subsubsection{Photovoltaic devices using black-Si formed by NACE}

To check if the proposed NACE technology can be applied to form photovoltaic devices, we prepared a set of photovoltaic devices the surfaces of which were textured by diverse methods, namely perfectly polished, with the pyramid layer made by $\mathrm{KOH} / \mathrm{IPA}$ etching and the black-Si layer made by using NACE. 


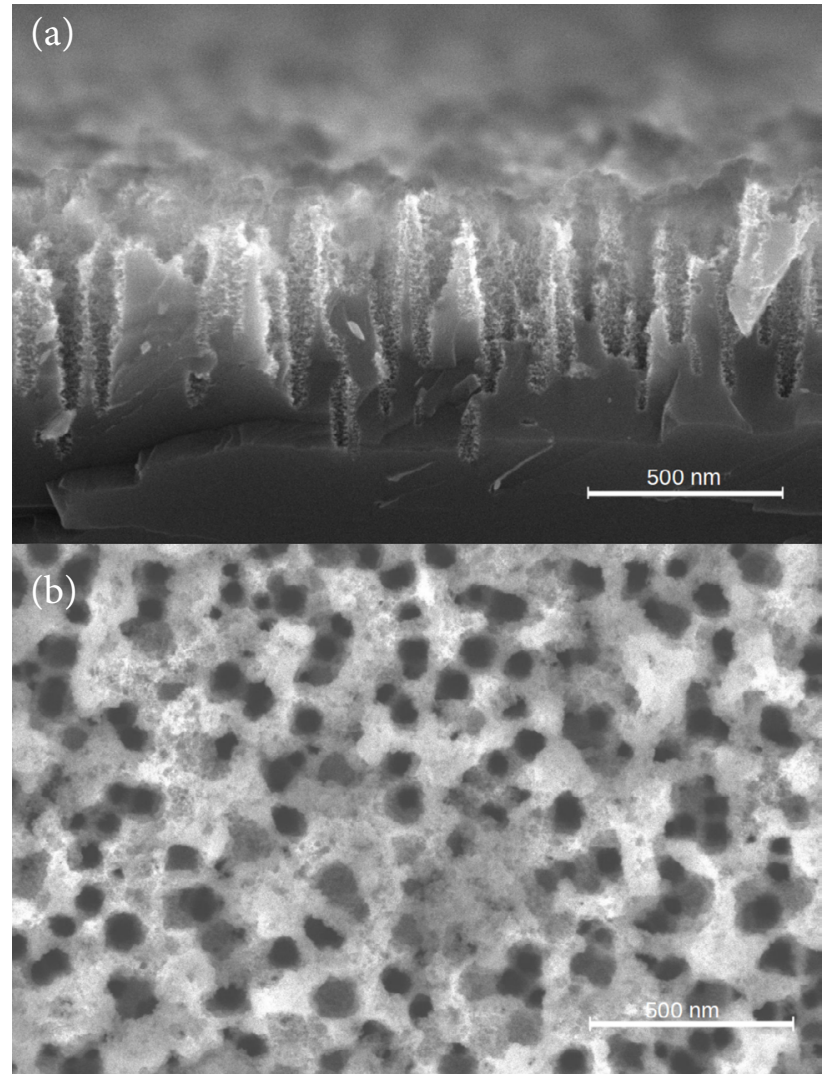

Fig. 9. Profile (a) and top (b) SEM pictures of the black-Si with the lowest reflectance formed by etching under the conditions with $\rho=9 \%$ and duration equal to $10 \mathrm{~min}$.

The parameters of the sample PV cells were measured using an AM 1.5 solar simulator. The $I-V$ characteristics of the devices are illustrated in Fig. 10, and the calculated parameters of devices are presented in Table 2.

The results in Table 2 demonstrated that the black-Si made by the NACE technique was improved compared to the $\mathrm{c}$-Si based photovoltaic device. However, the parameters were comparable to that of the samples with the KOH/IPA textured surfaces. It must be noted here that the formation of contacts on the textured surfaces is still an issue, and it typically resulted in worsening of the cell parameters. Therefore, the results in Fig. 10 and Table 2 are highly promising for further development because a simple and accurate control and cheapness of the process can be used to reduce the formation time of black-Si in the process lines with the industrial vacuum technologies when a combination of diverse methods is quite complicated. In addition, it must be noted here that our results do not represent the parameters of the completed PV

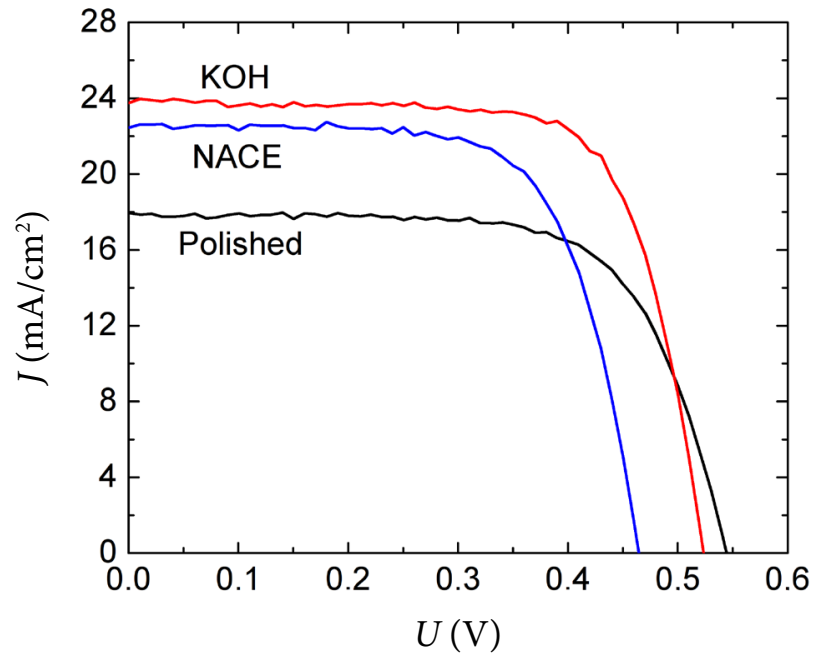

Fig. 10. $I-V$ curves for the photovoltaic devices with diverse c-Si surfaces: the standard polished surface, textured by standard $\mathrm{KOH}$-based etching and the NACE proposed in this work.

Table 2. Parameters of photovoltaic cells fabricated as standard polished surface cells, textured by commonly used $\mathrm{KOH}$-based method and textured by the modified NACE proposed in this work.

\begin{tabular}{cccc}
\hline $\begin{array}{c}\text { Surface } \\
\text { preparation }\end{array}$ & $J_{\mathrm{sc}} \mathrm{mA} / \mathrm{cm}^{2}$ & $F F, \%$ & $\eta, \%$ \\
\hline Polished surface & 17.93 & $68.8 \pm 2$ & $6.67 \pm 0.3$ \\
\hline NACE & 22.45 & $70.2 \pm 1.9$ & $7.25 \pm 0.2$ \\
\hline KOH etching & 23.75 & $73 \pm 1.6$ & $9.02 \pm 0.3$ \\
\hline
\end{tabular}

cells because we are focusing on the development of the features of the NACE method. The cell parameters were significantly reduced by the surface leakage conductance. Therefore, the surface protecting coating and the contact formation methods must be developed before the PV cell parameters can be reliably compared to those of commercially available solar cells.

\section{Summary}

In this study, we introduced a modified metal-assisted etching method based on the replacement of nanoparticles of metal catalysts with a continuous ultra-thin nickel layer that can be deposited on a large area of substrates by a conventional industrial sputtering device acceptable to form a black-Si layer. Our study proved that the roughness of the surfaces can be effectively changed even if the surfaces were covered by considerably large 
Ni strips. Our findings allow one to significantly simplify the control of the process for black-Si manufacturing. In addition, it was proved that the optical reflectance can be drastically minimized by optimizing the etchant $\rho$ parameter and the etching duration. Based on our original technology, the lowest minimal reflectance was obtained equal to $\sim 0.4 \%$ and the average reflectance was about $\sim 2 \%$. In addition, it was proved that the intentional changes in the parameters of $\mathrm{Ni}$ strips resulted in a specific tuning of the characteristics of black-Si. Our experimental study also demonstrated that the original NACE method was acceptable to modify the parameters of the Si PV solar cell model. It is important to note here that the method is compatible with the standard Si PV cell production routine and requires a cheap metal catalyst that, in contrast with the typical precious metal nanoparticles, can be easily removed from the $\mathrm{Si}$ surfaces after the procedure. Considering all these facts, we claim that the NACE method can be effectively adapted for the modification of the surfaces of PV devices.

\section{Acknowledgements}

This research was funded by a Grant (No. MIP70/2015) from the Research Council of Lithuania.

We would also like to thank Dr. Algirdas Selskis from the Department of Characterisation of Materials Structure, Center for Physical Sciences and Technology for the SEM pictures.

\section{References}

[1] F. Chigondo, From metallurgical-grade to solargrade silicon: An overview, Silicon 10(3), 789-798 (2018), https://doi.org/10.1007/s12633-016-9532-7

[2] J. Lv, T. Zhang, P. Zhao, and Sh. Li, Review application of nanostructured black silicon, Nanoscale Res. Lett. 13, 110 (2018), https://doi.org/10.1186 s11671-018-2523-4

[3] X. Liu, P.R. Coxon, M. Peters, B. Hoex, J.M. Cole, and D.J. Fray, Black silicon: fabrication methods, properties and solar energy applications, Energy Environ. Sci. 7(10), 3223-3263 (2014), https:// doi.org/10.1039/C4EE01152

[4] B. Iandolo, A.P. Sanchez Nery, R.S. Davidsen, and O. Hansen, Black silicon with ultra-low surface recombination velocity fabricated by inductively coupled power plasma, Phys. Status Solidi Rapid Res. Lett. 13(2), 1800477 (2019), https://doi. org/10.1002/pssr.201800477

[5] M.H. Shiao, C.P. Lai, B.H. Liao, and Y.S. Lin, Effect of photoillumination on gold-nanoparticle-assisted chemical etching of silicon, J. Nanomater. 2018, 5479605 (2018), https://doi. org/10.1155/2018/5479605

[6] R. Venkatesan, M.K. Arivalagan, V. Venkatachalapathy, J.M. Pearce, and J. Mayandi, Effects of silver catalyst concentration in metal assisted chemical etching of silicon, Mater. Lett. 221, 206-210 (2018), https://doi.org/10.1016/j.matlet.2018.03.053

[7] A.V. Takaloo, M. Kolahdouz, J. Poursafar, F. Es, R. Turan, and S. Ki-Joo, Fabrication of low reflective nanopore-type black Si layer using one-step $\mathrm{Ni}$-assisted chemical etching for Si solar cell application, Mater. Res. Express 5(3), 035905 (2018), https://doi.org/10.1088/2053-1591/aab2ee

[8] K. Gao, H. Shen, Y. Liu, Q. Tang, Y. Jiang, W. Yang, Y. Li, and Ch. Huang, Fabrication of black silicon by $\mathrm{Ni}$ assisted chemical etching, Mater. Res. Express 5(1), 015020 (2018), https://doi. org/10.1088/2053-1591/aaa1fb

[9] M. Treideris, A. Reza, M. Kamarauskas, V. Agafonov, and A. Setkus, in: Proceedings of the 33rd European Photovoltaic Solar Energy Conference and Exhibition (2017) pp. 687-689, https://doi. org/10.4229/EUPVSEC20172017-2AV.2.36

[10]D. Necas and P. Klapetek, Gwyddion: an opensource software for SPM data analysis, Cent. Eur. J. Phys. 10(1), 181-188 (2012), https://doi. org/10.2478/s11534-011-0096-2

[11]X. Li and P.W. Bohm, Metal-assisted chemical etching in $\mathrm{HF} / \mathrm{H}_{2} \mathrm{O}_{2}$ produces porous silicon, Appl. Phys. Lett. 77(16), 2572-2574 (2000), https://doi.org/10.1063/1.1319191

[12]Z. Huang, N. Geyer, P. Werner, J. de Boor, and U. Gosele, Metal-assisted chemical etching of silicon: A review, Adv. Mater. 23(2), 285-308 (2011), https://doi.org/10.1002/adma.201001784

[13]C. Chartier, S. Bastide, and C. Levy Clement, Metal-assisted chemical etching of silicon in HF$\mathrm{H}_{2} \mathrm{O}_{2}$, Electrochim. Acta 53, 5509-5516 (2008), https://doi.org/10.1016/j.electacta.2008.03.009 
[14]R.M. Khalil, Kinetics of decomposition of hydrogen peroxide over different electrodeposited nickel powder catalysts, J. King Saud Univ. Sci. 2, 91-100 (1990).
[15]H. Han, Zh. Huang, and W. Lee, Metal-assisted chemical etching of silicon and nanotechnology applications, Nano Today 9, 271-304 (2014), https://doi.org/10.1016/j.nantod.2014.04.013

\title{
NIKELIU INICIJUOTO SILICIO ĖSDINIMO SALYGU ITAKA FOTOVOLTAIKAI SKIRTO JUODO SILICIO KOKYBEI
}

\author{
M. Kamarauskas, M. Treideris, V. Agafonov, A. Mironas, V. Strazdienè, A. Rėza, A. Šetkus \\ Fiziniu ir technologijos mokslų centras, Vilnius, Lithuania
}

\section{Santrauka}

Detaliai ištirtas būdas suformuoti juodo silicio sluoksnius su metalo inicijuotu èsdinimu naudojant nikelị kaip katalizatorių. Siūlomoje metodikos versijoje sunkiai kontroliuojamas nanodaleliu formavimo etapas yra pakeistas ištisinio ultraplono nikelio sluoksnio auginimu. Tekstūravimo procesas pagrịstas žinomais elektrocheminiame èsdinime medžiagos pernašos ir èsdinimo mechanizmais, pritaikytais prie didelio ploto plonų metalinių sluoksnių, dengiančių silicio paviršių, sistemos. Toks metodas leidžia suformuoti didelio ploto vienodas / tolygias juodo Si sritis. Pastebèta, kad didè-
\end{abstract}

jant katalizatoriaus storiui didèja èsdinamo paviršiaus šiurkštumas ir kartu mažèja atspindys nuo paviršiaus. Tiriant ésdiklio koncentracijos ịtaką nustatyta, kad mažiausias atspindys pasiekiamas, kai aktyviosios èsdinimo medžiagos kiekis ésdinimo tirpale yra mažas, ir kad optimalus èsdinimo laikas priklauso nuo èsdiklio koncentracijos (svyruoja 3-10 min.). Galiausiai juodo Si bandiniuose buvo suformuota $p n$ sandūra ir ištirtos elektrinès savybès. Rezultatai buvo palyginti su iprastinio paviršiaus apdorojimo saulès elementų elektrinèmis savybèmis. 